\title{
Geology and Petrology of Omzha Block, Zhob Ophiolite, northern Balochistan, Pakistan
}

\section{Ali Ahmed a, Muhammad Ishaq Kakara, Abdul Naeemb, Nisar Ahmed ${ }^{b}$, Mehrab Khanc, Muhammad Panezaia*}

aCentre of Excellence in Mineralogy, University of Balochistan, Quetta, Pakistan.

${ }^{\mathrm{b}}$ Geological Survey of Pakistan.

'Department of Earth \& Environmental Sciences, Bahria University (Karachi Campus), Pakistan.

*Corresponding Author E-mail: panezaimuhammad@gmail.com

\section{DOI: $10.2478 / p j g-2020-0008$}

\section{Abstract:}

The Zhob Ophiolite is divided into three detached blocks including the Omzha block. The Omzha block is mapped and divided into lithological units such as ultramafic rock, mafic-felsic rock, and volcanic-volcaniclastic-pelagic rocks. These units are quite deformed and mixed up and are associated with one another by thrust faults. Petrography and geochemistry divide them into gabbro, diorite, plagiogranite, pheno-tephrite and trachy-andesite basalt, trachy basalt, chert, limestone, and mudstone. The ultramafic rocks are dominantly serpentinized harzburgite, dunite, and a minor lherzolite. Petrography of peridotite shows that it may be depleted in nature and may have residual after processes such as partial melting and the melt-rock reaction of a lherzolitic source. The gabbroic rocks are less well-developed and highly deformed. They are cross-cut by diorite, plagiogranite and anorthosite' intrusions. The gabbro may be the plutonic section of Omzha block' crust while the intermediate-felsic igneous rocks may have formed by the anataxis of crustal gabbro. The volcanic-volcaniclastic-pelagic rocks unit may be corrected with Bagh complex found underneath the Muslim Bagh Ophiolite. The metamorphic sole rocks of Omzha block are highly deformed and dismembered are comprising of metamorphic facies such as amphibolite, quartz-mica schist, and greenschist.

Keywords: Ophiolitic mélange, ultramafic rocks, gabbro, plagiogranite, volcanics- volcaniclastics. metamorphic sole rocks

\subsection{Introduction}

The ophiolites are the pieces of oceanic lithosphere tectonically emplaced on continental margins, incorporated in island arcs and found as deformed and altered blocks in the collision belts [1]. The ophiolites are either intact showing a complete or nearly complete stratigraphy or dismembered [2]. When an ophiolite is so dismembered and deformed that it is not possible to reconstruct to its stratigraphic sequence that ophiolite may be called a mélange [3]. The ophiolites and its underlying mélanges have a great significance in the geological history of suture zones occupied by them. Determining the nature and ages of the lithological units of the ophiolite mélanges pave the way to reconstruct their tectonic evolution, from their origin to their final emplacement [4].

In Pakistan, the ophiolite complexes are exposed both along the northern and western suture of the Indian Plate with Afghan block [5]. The larger bodies of these ophiolites are those that are exposed along the western suture in Balochistan namely; Bela, and Zhob valley ophiolites [6]. The Zhob valley ophiolites consist of, Muslim Bagh Khanozai and Zhob ophiolites [7]. The Zhob ophiolite is located near the Pak-Afghan Border and is the northernmost exposure of the ophiolites of Balochistan. The three dismembered blocks of Zhob ophiolite are namely; Omzha block, Ali Khanzai block and Naweoba block. The geology of Naweoba and Ali Khanzai blocks are reported elsewhere while the Omzha block has almost all the units of a complete ophiolite but not arranged in a stratigraphic manner. The Omzha block has been mapped here (Figure 1). The rock's units of the block are quite deformed and mixed up and give a sense of a mélange, where large blocks of serpentinized peridotite, Mafic-felsic rock, metamorphic rocks are distributed in a host unit of volcanicvolcaniclastic-pelagic rocks. For the first time, this paper reports the geology, petrography and major element geochemistry of the rocks of Omzha block, which has been discussed to determine their nature.

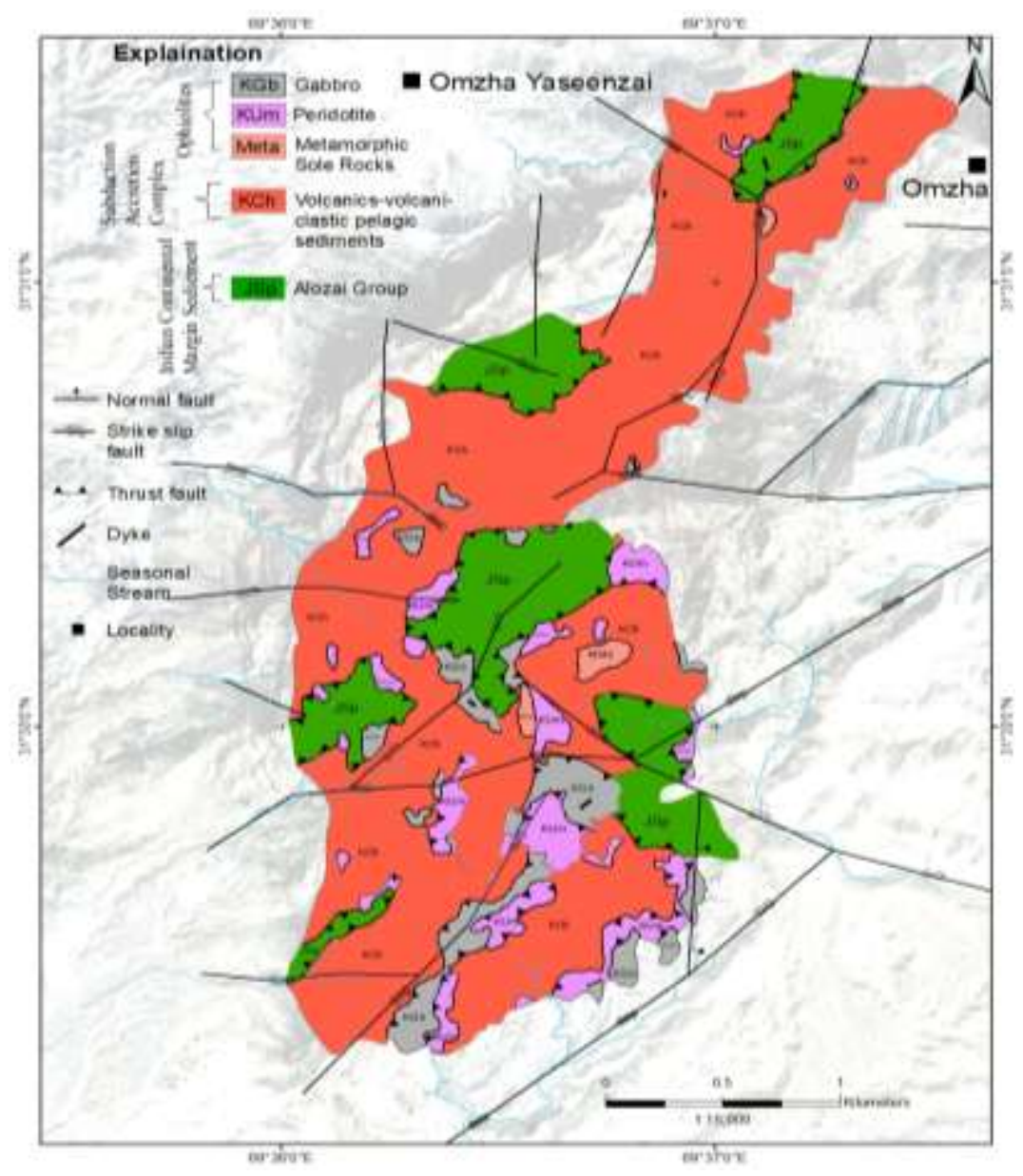


Figure 1: Geological map of Omzha block of the Zhob Ophiolite, Northern Balochistan, Pakistan.

\subsection{Geology of Zhob area and Zhob Ophiolite}

Geology of the Zhob area could be divided into (1) Calcareous belt, (2) suture belt (ophiolite complexes), and (3) flysch belt. The Calcareous belt is tectonically the lowermost belt, which is the northwestern passive margin of the Indian continent and is immediately underlying the Zhob Ophiolite. The Calcareous belt is comprised of lithologies such as limestone, mudstone, shale, and sandstone which is varying in age from Triassic (Wulgai Formation) to middle Jurassic (Alozai Group) [8]. The Suture belt is thrusted over the Calcareous belt Sengor, which lies between the Indian plate and the Afghan block Allemann, and comprises Zhob valley ophiolites complexes [9-11]. The three detached blocks of the Zhob Ophiolite are Naweoba block, Ali Khanzai block and Omzha block Jones, Manistre, in which the Naweoba block is the largest and Omzha block is the smallest blocks of three bodies [12]. All the three blocks of Zhob Ophiolite comprises of a mix of the ophiolitic sequence rock, including metamorphic sole rocks. The Flysch belt Naka, Kimura, also called the Pishinflysch belt Kasi, Kassi, which lies to the north of the suture belt $[13,14]$. The oldest rocks formation of the belt (Eocene Nisai Formation) is unconformably overlying the ophiolite [10]. The Nisai Formation is succeeded by Oligocene Khojak Formation Qayyum, Niem Pliocene-Pleistocene Multana Formation $[12,15]$.

\subsection{Materials and Methods}

Extensive fieldwork has been carried out in the Omzha block of the Zhob area, and the Google Earth feature was used for mapping (Figure 1). About 50 rock samples are collected from different rocks unit of the ophiolite, for petrographic and geochemical studies. For the petrographical studies, about thirty-five thin sections were prepared and analyzed under Olympus BX51 Fluorescence Microscope at the laboratory of the home department, University of Balochistan, Quetta, Pakistan. For geochemistry a total of twenty, least altered samples were selected from different ophiolitic rocks of the Omzha block including ( 6 samples from gabbroic rocks, 5 from granitic rocks, 5 from volcanic rocks and 4 from dolerite dikes). Analytical methods applied to determine the concentration of major and trace elements include XRF and AAS. The weathered surfaces were removed before analysis, and the samples were crushed and powdered by using a mill and a jaw crusher and made them powdered $(<0.074 \mathrm{~mm})$. The powdered samples were dried and heated up for three hours at $900^{\circ} \mathrm{C}-950^{\circ} \mathrm{C}$ for determining the loss on ignition (LOI). Powder of the samples was heated at $110^{\circ} \mathrm{C}$ for five hours to remove the absorbed moisture and to determine their major element composition through XRF. The samples were cooled to gain room temperature in a desiccator, and then the sample was mixed with lithium tetraborate $\left(\mathrm{Li}_{2} \mathrm{~B}_{4} \mathrm{O}_{7}\right)$ flux at a specific ratio (1:5), and then the resultants were pressed to form a disc. The fused disc was analyzed for major element concentration using a WD-XRF. The composition of trace elements such as $\mathrm{Cr}, \mathrm{Ni}, \mathrm{Co}, \mathrm{Zn}, \mathrm{Cu}$, and $\mathrm{Pb}$ from the powdered sample was determined through AAS. These powdered samples were dissolved, using hydrofluoric acid and aqua-regia $\left(3 \mathrm{HCl} 1 \mathrm{HNO}_{3}\right)$ to get liquid solutions [16]. The solutions of the samples were run in Atomic Absorption Spectrometer (AAS) using the same cathode lamp of the sample and the values are noted in ppm (Table 1).

Table 1: Major oxide (wt \%) and selected trace element (ppm) concentration of the analyzed samples from the Omzha block of Zhob Ophiolite.

\begin{tabular}{|c|c|c|c|c|c|c|c|c|c|c|c|c|c|c|c|c|c|c|c|}
\hline $\begin{array}{l}\text { Sample } \\
\text { No }\end{array}$ & $\begin{array}{l}\text { OM- } \\
01\end{array}$ & $\begin{array}{l}\text { OM- } \\
03\end{array}$ & $\begin{array}{l}\text { OM- } \\
05\end{array}$ & OM-06 & $\begin{array}{l}\text { OM- } \\
10\end{array}$ & $\begin{array}{l}\text { OM- } \\
12\end{array}$ & $\begin{array}{l}0 M- \\
14\end{array}$ & $\begin{array}{l}\text { OM- } \\
16\end{array}$ & $\begin{array}{l}\text { OM- } \\
19\end{array}$ & $\begin{array}{l}\text { OM- } \\
25\end{array}$ & $\begin{array}{l}\text { OM- } \\
\mathbf{3 0}\end{array}$ & $\begin{array}{l}\text { OM- } \\
33\end{array}$ & $\begin{array}{l}\text { OM- } \\
36\end{array}$ & $\begin{array}{l}\text { OM- } \\
43\end{array}$ & $\begin{array}{l}\text { OM- } \\
44\end{array}$ & OM-46 & $\begin{array}{l}\text { OM- } \\
47\end{array}$ & $\begin{array}{l}\text { OM- } \\
48\end{array}$ & $\begin{array}{l}\text { OM- } \\
49\end{array}$ \\
\hline $\begin{array}{l}\text { Rock } \\
\text { type }\end{array}$ & D & D & B & $\mathbf{G r}$ & D & D & Gb & B & B & Gb & Gb & B & B & Gr & Gb & $\mathbf{G r}$ & Gr & Gb & $\mathbf{G r}$ \\
\hline $\mathrm{SiO}_{2}$ & 48.66 & 52.01 & 47.61 & 56.88 & 51.06 & $\begin{array}{l}48.66 \\
\end{array}$ & 42.85 & 47.15 & 46.50 & 46.82 & 35.77 & 55.32 & $\begin{array}{l}4.82 \\
\end{array}$ & 55.71 & 40.82 & 60.35 & 64.35 & 47.18 & 55.01 \\
\hline $\mathrm{TiO}_{2}$ & 0.91 & 0.07 & 0.91 & 0.00 & 0.07 & 0.93 & 0.01 & 0.16 & 0.41 & 0.02 & 0.01 & 0.13 & 0.53 & 0.03 & 0.01 & 0.04 & 0.04 & 0.03 & 0.01 \\
\hline $\mathrm{Al}_{2} \mathrm{O}_{3}$ & 19.88 & 23.06 & 18.82 & 25.66 & 23.08 & 19.88 & 21.07 & 21.11 & 19.11 & 26.69 & 32.52 & 23.14 & 28.36 & 30.42 & 29.98 & 28.12 & 23.34 & 30.15 & 32.12 \\
\hline $\mathrm{Fe}_{2} \mathrm{O}_{3}$ & 8.49 & 0.65 & 8.49 & 0.03 & 0.65 & 8.41 & 0.16 & 0.08 & 0.20 & 0.26 & 0.59 & 0.00 & 0.38 & 0.50 & 0.38 & 0.02 & 0.00 & 0.00 & 0.01 \\
\hline Mno & 0.13 & 0.04 & 0.13 & 0.00 & 0.04 & 0.13 & 0.01 & 0.06 & 0.03 & 0.02 & 0.01 & 0.02 & 0.06 & 0.01 & 0.02 & 0.05 & 0.02 & 0.01 & 0.00 \\
\hline MgO & 8.22 & 15.82 & 8.22 & 0.07 & 16.82 & 8.22 & 20.30 & 10.55 & 10.20 & 16.89 & 20.29 & 8.83 & 15.14 & 11.29 & 12.41 & 1.74 & 1.74 & 11.80 & 8.80 \\
\hline $\mathrm{CaO}$ & 7.88 & 4.10 & 7.88 & 0.54 & 4.10 & 7.88 & 4.74 & 2.29 & 8.32 & 6.99 & 4.64 & 4.17 & 4.78 & 3.64 & 2.76 & 0.01 & 0.81 & 2.20 & 3.20 \\
\hline $\mathrm{Na}_{2} \mathrm{O}$ & 5.46 & 3.02 & 5.36 & 17.19 & 3.02 & 4.46 & 0.00 & 7.42 & 0.00 & 0.00 & 2.85 & 7.34 & 4.93 & 2.88 & 8.51 & 3.34 & 9.43 & 4.13 & 5.13 \\
\hline $\mathrm{K}_{2} \mathrm{O}$ & 0.24 & 0.14 & 0.24 & 0.03 & 0.14 & 0.24 & 0.80 & 6.09 & 0.41 & 0.01 & 1.20 & 0.02 & 0.05 & 2.30 & 0.09 & 0.20 & 0.32 & 0.49 & 0.02 \\
\hline $\mathrm{P}_{2} \mathrm{O}_{5}$ & 0.12 & 0.02 & 0.12 & 0.00 & 0.02 & 0.13 & 0.01 & 0.09 & 0.52 & 0.02 & 0.01 & 0.07 & 0.96 & 0.02 & 0.00 & 0.00 & 0.05 & 0.00 & 0.04 \\
\hline LOI & 2.60 & 2.85 & 3.30 & 0.45 & 4.25 & 3.00 & 8.45 & 7.30 & 17.05 & 5.70 & 6.50 & 5.4 & 9.20 & 0.80 & 4.90 & 6.35 & 1.60 & 4.55 & 0.4 \\
\hline Total & 97.13 & 101.76 & 101.08 & 100.85 & 103.25 & 101.94 & 98.40 & 102.30 & 102.75 & 103.42 & 101.54 & 104.44 & 109.21 & 104.60 & 99.88 & 100.00 & 101.70 & 100.54 & 101.74 \\
\hline Co & 37 & 27.75 & 31.45 & 14.65 & 64.3 & 34.35 & 46.45 & 53.9 & 34.7 & 34.6 & 13 & 31.3 & 48.9 & 12.7 & 37.5 & 26.45 & 48.15 & 23.1 & 16.15 \\
\hline Cr & 2.8 & 2.4 & 42.9 & 0.5 & 37.8 & 26.75 & 122.8 & 1.0 & 11.5 & 9.6 & 63.5 & 81.65 & 35.7 & 2.55 & 100.7 & 3.7 & 00 & 254.9 & 00 \\
\hline $\mathbf{N i}$ & 7.85 & 7.65 & 16.55 & 00 & 82.4 & 43.95 & 314.0 & 3.65 & 28.3 & 77.77 & 163.0 & 75.6 & 36.6 & 00 & 85.5 & 84.85 & 00 & 53.7 & 00 \\
\hline $\mathrm{Cu}$ & 933.5 & 168.0 & 437.1 & 350.3 & 226.3 & 274.2 & 50.7 & 96.55 & 56.25 & 200.9 & 61.4 & 406.0 & 188.7 & 188.1 & 52.75 & 89.55 & 755.5 & 86.25 & 551.5 \\
\hline Pb & 3.35 & 30.7 & 25.35 & 16.15 & 14.25 & 11.3 & 4.85 & 40 & 74.05 & 58.5 & 56.85 & 55.95 & 58.45 & 22.7 & 36.65 & 32.7 & 36.85 & 12.3 & 42.15 \\
\hline $\mathrm{Zn}$ & 33.2 & 56.85 & 25.55 & 12.8 & 37.95 & 57.6 & 19.6 & 80.55 & 62.2 & 22.35 & 18.65 & 57.4 & 142.7 & 21.65 & 24.6 & 19.0 & 32.35 & 16.15 & 9.25 \\
\hline
\end{tabular}

Note: $\mathrm{OM}=$ Omzha block, LOI = loss on ignition, Fe2O3=total iron, $\mathrm{D}=$ dolerite, $\mathrm{B}=$ basalt,GB=gabbro, Gr=granite

\subsection{Results}

\subsection{Field Features}

\subsubsection{Ultramafic Rock Unit}

Generally, there are two types of ultramafic units of an ophiolite; (i) ultramafic tectonite and (ii) ultramafic cumulate, but in the Omzha block of Zhob Ophiolite, it is not possible to divide them into tectonite and cumulates units, because the rocks are deformed and tectonically disturbed. Although the ultramafic rocks are identified as lherzolite, harzburgite, dunite, and wehrlite. Overall most of the ultramafic rocks are moderate to wholly altered into serpentinite. The ultramafic rock units in the Omzha block are small bodies and exposed in an irregular form, which may easily be distinguished from gabbro, basalt and sedimentary rocks unit (Figure 1). The ultramafic rock unit has a structural contact with different rocks, but mostly they are in contact with gabbroic rocks (Figure 2a-b).

Lherzolite is found in Solingai Tangi southeast of the Omzha block. It is olive-green on fresh surfaces and black-brown to dark brownish on weathered surfaces. Lherzolite is medium to coarse-grained and granular. Massive bodies of the harzburgite are extensive in the ultramafic rock unit, which generally shows serpentinization. The harzburgite is of greenish-black to dark brown, medium to coarse-grained and porphyroclastic in texture. The weathered color of dunite is light grayish while fresh color is greenish-gray. It is partially to completely altered into serpentinite. A small concentration of chromites is found in dunite as, in the form of lenses, disseminated and pod. Wehrlite and pyroxenite are found as small bodies and are not mappable. 

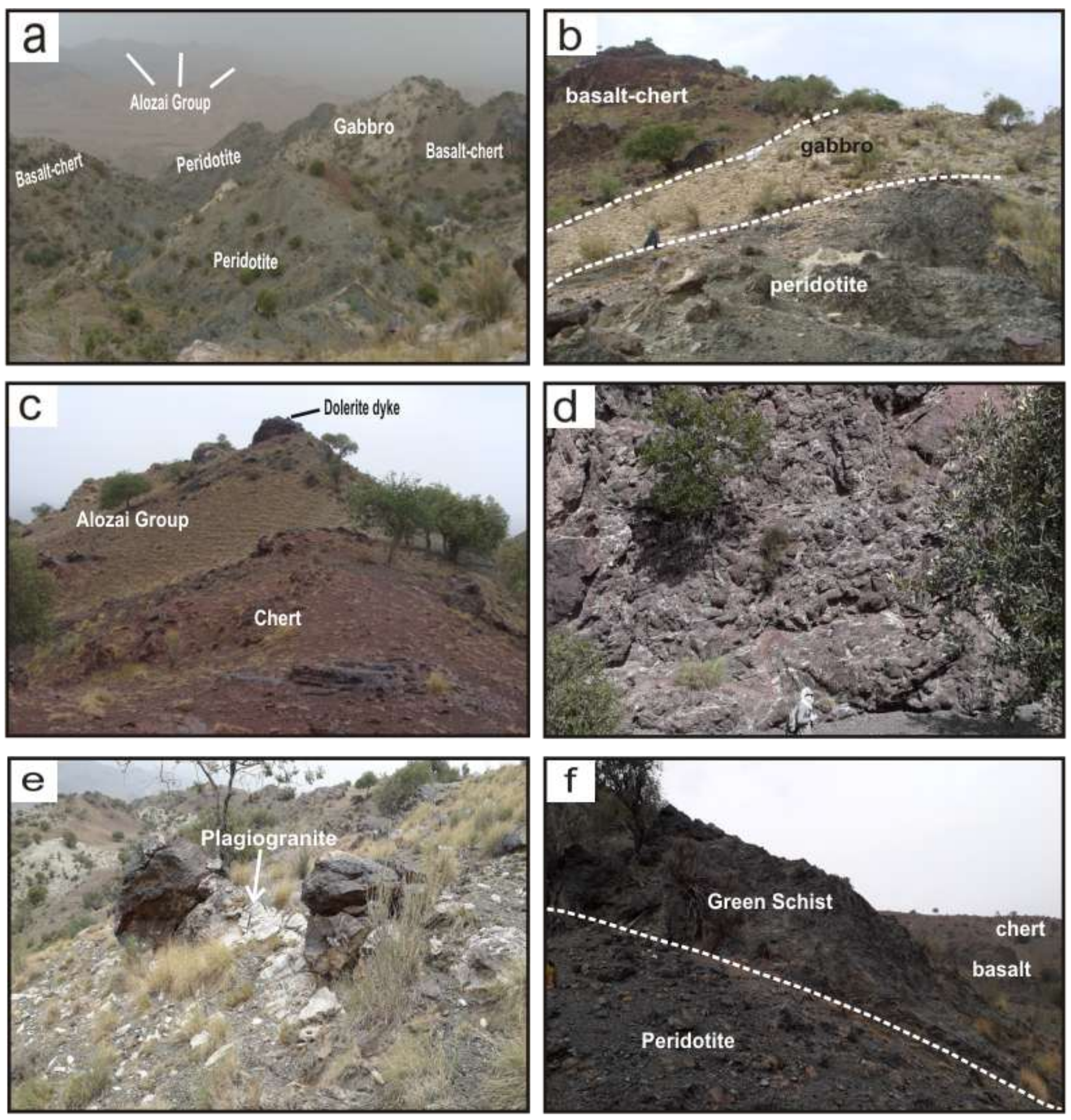

Figure 2: Field Photographs showing: (a) an overview of different rock units exposed in the stream flowing towards Omzha Yaseenzai village; (b) Gabbroic rock in thrust contact with peridotite at the base and basalt-chert unit at the top; (c)The dolerite dike in sedimentary rocks; (d)Pillow basalt in volcanic rocks in Nishpa stream;(e) Plagiogranite dike in gabbroic rocks is found on the western side of the Omzha block; (f) Green schist has a structural contact with peridotite found in Nishpa stream.

\subsubsection{Mafic-Felsic Rock Unit}

Small and detached bodies of gabbro are extensively exposed in the southern portion of the Omzha block (Figure 1). These rocks are whitish-grey to dark grey and both medium-grained and coarse-grained. It is very less well-developed and highly deformed. We have not found a sheeted dike complex in the Omzha block. The gabbroic rocks have a structural contact both with peridotite and volcanic-volcaniclastic rocks (Figure 2a-b). The gabbroic rocks have both light (plagioclase) and ferromagnesian (pyroxene) minerals. Intermediate to acidic intrusive rocks are enclosing by gabbroic rocks. They are mainly plagiogranite and anorthosite found in the form of veins, dikes and massive bodies within the crustal section of Omzha block (Figure 2e).

\subsubsection{Volcanic-Volcaniclastic-Pelagic Rocks}

This unit is the largest unit of the mapped area, covering more than $60 \%$ of the studied area and are more extensive toward the northern side of the block (Figure 1). The volcanic-volcaniclastic-pelagic rocks unit is composed of thick pillow lava, associated with hyaloclastite, bedded chert, pelagic limestone, and hemipelagic mudstone. The unit has a thrusted contact with other mapped rock units such as gabbro, peridotite and sedimentary rocks (Alozai Group; Triassic-Jurassic). In the outcrop, the volcanic rocks are dark brownish to green in color and are associated with hyaloclastite. The hyaloclastite contains fragments of volcanic rocks, ultramafic rocks, and limestone. The structures found in volcanic rocks have sheet flows, tubes, and pillows. Pillows are circular or oval and are deformed. The cracks in pillows are filled in by secondary calcite and quartz vein (Figure $2 \mathrm{~d}$ ). The pelagic sediments generally overlie the volcanic rocks and other rocks unit, mostly due to tectonic contacts. The pelagic sediments comprise of chert, cherty shale and limestone. Multi-color chert is highly compact, in which the red color is more abundant (Figure 2a-c). The volcanic rocks of the Omzha block are also characterized by the existence of vesicular and amygdaloidal structures. The vesicular structures are found rarely and the vesicles are tiny in size. Amygdule is mainly secondary quartz, 
calcite, and zeolite. This structure can be observed frequently and abundant in the volcanic rocks of Omzha block.

\subsubsection{Mafic Dike}

Mafic dikes are intruded discordantly in the mantle rocks of the block, they are also found cross-cutting through sedimentary rocks and are not found in volcanic rocks. The dikes are sporadically distributed with a random orientation. These dikes are mostly altered into rodingite and the chill margins are not observed along the dikes. The thickness of the dikes range from $1 \mathrm{~m}$ to $3 \mathrm{~m}$ and may extend up along the strike to many meters (Figure $2 \mathrm{c}$ ).

\subsubsection{Metamorphic Sole Rocks}

The metamorphic sole rocks are exposed in the middle and at different localities in the Omzha block of the Zhob Ophiolite. The metamorphic sole rocks have a faulted contact with peridotite and gabbro. These metamorphic rocks are identified as amphibolites, quartz-mica schist, and greenschist. Microstructures such as foliation and lineation are found in all the exposures of metamorphic rocks (Figure 3f).
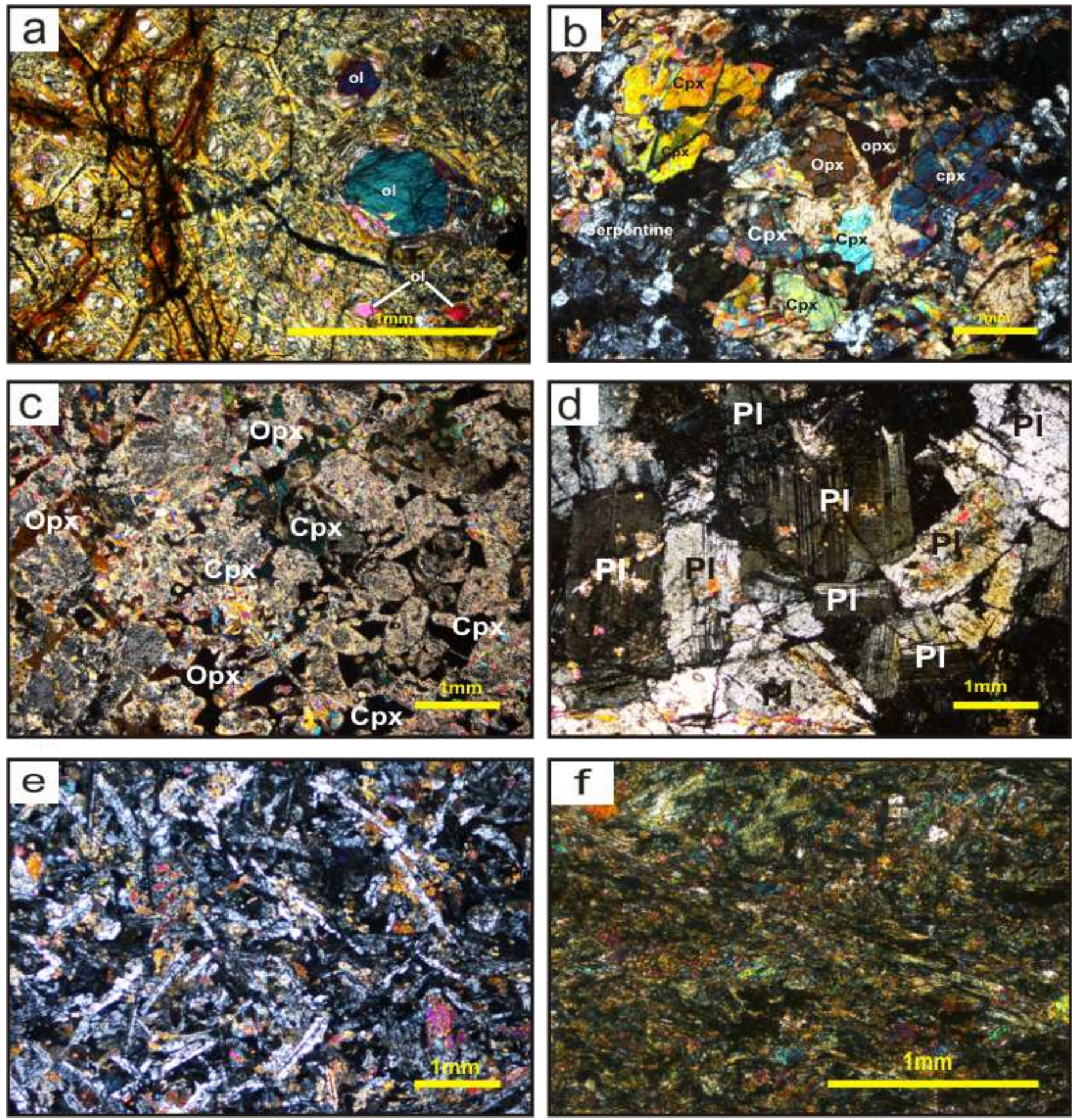

Figure 3: a-f; Microphotographs: (a) Dunite showing the relict core of olivine enclosed in serpentine mesh with porphyroblastic texture and the magnetite and other opaque minerals are highly oxidized (XPL).(b) Lherzolite showing partially altered orthopyroxene and clinopyroxene and talc and olivine with hypidiomorphic granular and granoblastic textures (XPL); (c) Gabbroic rocks in which pyroxenes are surrounded by highly altered plagioclase (XPL);(d) Anorthosite) composed of wholly of plagioclase with minor inclusion of clinopyroxene, showing holocrystalline, hypidiomorphic and granular textures (XPL);(e) Dolerite composed of plagioclase, clinopyroxene, and minor opaque minerals, showing subhedral to anhedral crystals which are arranged in intersertal, intergranular and sub-ophitic manners (XPL);(f) Greenschist is composed of chlorite, plagioclase with accessory minerals such as epidote, quartz, and opaque minerals. The grains are typically fine to medium-grained, with sub-parallel orientation, which helps to form schistosity (XPL). 
The sedimentary rocks surrounding the Omzha block is Alozai Group (Triassic-Jurassic). The Alozai Group has a thrust contact with all units of Omzha block (Figure 2a-c). The group has two members; (a) Spingwar Formation (Early Jurassic to upper Triassic) and (b) Loralai Formation (Early to Middle Jurassic).

\section{(a) Loralai Formation}

The formation is introduced after the Loralai town [12]. The Loralai Formation dominantly comprises of limestone with subordinate shale and marl. The formation is found to the northwest of the Omzha block and is thick-bedded limestone, marl and shale interbedded. The limestone is grayish-dark to brownish-gray, fine-grained and breaks with a conchoidal fracture. The shale is calcareous and grey to black in color. The marl is soft and greenish-grey.

\section{(b) Spingwar Formation}

The Spingwar Formation was firstly introduced by Williams and recently, Fatmi, Hyderi included it in the Alozai Group [17,18]. This formation is exposed on the southern side of the Omzha block. Mostly, the Spingwar Formation is thrusted by the Volcanic-Volcaniclastic-Pelagic rocks unit, but in the Sahafi Tangi, it is thrusted back on ultramafic rocks unit. The formation is comprises of thin interbedded limestone and calcareous shale. The limestone is dark gray and marly.

\subsection{Petrography}

\subsubsection{Lherzolite}

Lherzolite is medium to coarse-grained, having interlocking and equigranular textures. It is less altered than harzburgite and dunite. It contains mainly olivine, clinopyroxene, orthopyroxene, with minor amounts of opaque and secondary minerals such as serpentines, chlorite, and talc (Figure 3b). In most samples, the olivine is replaced by serpentine, and the associated pyroxenes are partly altered to chlorite and talc. The opaque minerals are very minor than dunite and harzburgite. The modal composition of lherzolite is olivine (7-15\%), serpentine (45-65\%), orthopyroxene (10-20\%), clinopyroxene and chrome spinel (1-3\%).

\subsubsection{Harzburgite}

Harzburgite is the most abundant ultramafic rock in the Omzha block of Zhob Ophiolite. It is granoblastic and hypidiomorphic texturally, and medium to coarse-grained. The essential minerals of the harzburgite are olivine and orthopyroxene with accessory opaque minerals such as iron oxide and spinel. The altered product is serpentine. Olivine is anhedral to subhedral in shape and strongly altered to serpentine. Orthopyroxene is subhedral to euhedral, which is mostly enstatite and partially to completely altered into chlorite. The spinel is a euhedral to subhedral in shape, is dispersed throughout in the groundmass. In some samples, iron oxide is found as a complex network of veins. The modal composition of harzburgite is orthopyroxene (20-38\%), olivine (7-15\%), serpentine (50-65\%), chrome spinel (4-7\%) and with minor clinopyroxene.

\subsubsection{Dunite}

Dunite is medium-grained to coarse-grained, and it shows subhedral to euhedral and hypidiomorphic textures. Mineralogically, dunite is mainly composed of olivine with accessory minerals like pyroxene and opaque grains. Olivine is replaced by serpentine, however, in some samples, the relicts of olivine are still reserved, in a fine to medium-grained serpentine mesh. The opaque minerals are chromite, iron oxide, the former is found as granular, and the latter one is found as dark color veins (Figure 3a). The modal composition of dunite is summarized olivine (10\%-22\%), serpentine (60- 75\%), pyroxene (3\%$10 \%)$ and chrome spinel (3\%-8\%).

\subsubsection{Gabbroic rocks}

The gabbroic rocks are highly deformed and display granular, mylonitic and porphyroclastic textures. Petrographically, they are medium to coarse-grained, hypidiomorphic to subophitic in textures. Plagioclase and clinopyroxene (augite, diopside) are arranged in intergranular and sub-poikilitic manners (Figure 3c-d). In most of the thin sections, plagioclase is found as a lath, but in some thin sections, it is highly deformed and altered which does not show its features, such as twinning and doesn't determine its solution series. It generally shows polysynthetic twinning and is partially to highly altered and replaced by epidote and sericite. Clinopyroxene is the second abundant mineral, which is anhedral to subhedral in shape and medium to coarse-grained in size. It is weakly pleochroic and highly colored, it is slightly altered to chlorite and talc. A very minor amount of orthopyroxene is found, which shows a marked pleochroism. Generally, clinopyroxene is found as poikilitic and interlocking contact with plagioclase and some are found as inclusions in plagioclase. Hornblende is found in some thin sections, which shows strong pleochroism. The cleavage is disturbed, due to its high deformation. The modes of the gabbroic rocks are summarized as plagioclase (55-75\%), clinopyroxene (12-35\%), orthopyroxene (8-20\%) and with accessory and secondary products include opaque minerals, chlorite, sericite, and hornblende.

\subsubsection{Granitic rocks}

The granitic rocks of Omzha block are primarily composed of quartz, k-feldspar and plagioclase feldspar with minor amounts of pyroxene, biotite, hornblende, and opaque minerals. In some thin sections, they are inequiganular, display anhedral phenocryst phases of quartz, pyroxene, and plagioclase are surrounded by a fine-grained groundmass composed of quartz, plagioclase, pyroxene, and potassium feldspar, while in most thin sections, the grains are wholly medium to coarse-grained with intergrowth texture. Quartz is anhedral, medium to fine-grained and is giving undulose extinction. Potash feldspar is mostly orthoclase, having microperthitic texture and few are microcline, with Carlsbad twinning. Plagioclase is subhedral to anhedral with multiple albite twinning. Pyroxenes are highly altered and replaced by chlorite. The modal composition of the granitic rock is summarized as quartz (35$55 \%)$, k-feldspar (20-35\%), plagioclase feldspar (20-25\%) and with minor biotite.

\subsubsection{Basalt}

The basalt is characterized by porphyritic to non-porphyritic and amygdaloidal textures. It is mainly composed of phenocryst of plagioclase, pyroxene with minor amphibole, olivine and opaque minerals. Plagioclase is the most abundant constituent by volume and found both in the form of fine acicular laths with random orientation and as well as the phenocrysts. Plagioclase is subhedral to anhedral and frequently shows polysynthetic twinning. Due to the finegrained size and alteration of plagioclase, it is difficult to confirm its solution series member. Clinopyroxene is mostly augite, which is moderately altered into chlorite. Some olivine and amphibole are also found as phenocryst. Quartz and calcite are found as secondary materials, which form the amygdules by filling the vesicles or as a pseudomorph after replacing olivine.

\subsubsection{Dolerite}

Dolerites are medium to fine-grained in size and ophitic to subophitic texturally. They are mainly comprised of plagioclase, clinopyroxene, and amphibole with accessory biotite and opaque minerals. The secondary minerals are sericite, epidote, and chlorite. Plagioclase crystals occur as laths in pyroxene and hornblende. The plagioclase is partially to completely altered into sericite and epidote, so their primary composition is impossible to determine. The clinopyroxene is mostly augite, which is moderately altered into chlorite and amphibole (Figure 3e). The amphibole is brown to dark-green and highly pleochroic. The opaque minerals are magnetite, hematite, and pyrite. The modal composition of the dolerite is summarized as plagioclase (50-70\%), pyroxene (20-30\%), with accessory and secondary products are opaque (3-5\%), hornblende (3-6\%), chlorite (10-20\%), and sericite (5-15\%).

\subsubsection{Quartz-mica Schist}

The quartz-mica schist is predominantly composed of quartz, mica (muscovite) and plagioclase with a minor amount of biotite, epidote, and opaque minerals. These rocks show well-developed foliated texture due to partial segregation into light and dark color micro bands. The light color band consists of quartz and minor plagioclase while the dark color band consists of mica, chlorite, and biotite. The quartz-mica schist is porphyroblastic and the porphyroblasts are commonly quartz, plagioclase, and muscovite. Quartz is found as coarse porphyroblast to a very fine-grained. The muscovite shows 
mica-fish texture with elongate flakes and helps to make the foliation. In another thin section, the mica grains are twisted and disturbed the foliation, in that thin section, the porphyroblastic texture is absent, while the porphyroclastic texture is commonly found.

\subsubsection{Greenschist}

The greenschist is composed of chlorite, plagioclase with some accessory minerals such as actinolite, epidote, quartz, and opaque minerals. The rock is typically fine to medium-grained, with sub-parallel orientation, which helps to form schistosity (Figure 3f). Chlorite is the primary mineral and is pale green and weakly pleochroic. Plagioclase is highly deformed, and found as quant unzoned grain and the twinning is absent. The quartz is found in the accessory amount and commonly show xenoblastic form.

\subsection{Geochemistry}

To classify the plutonic and volcanic rocks of Omzha block, they are plotted on the total alkali versus $\mathrm{SiO}_{2}$ classification diagram (Figure 4a-b). The samples of the plutonic rocks variably plot within the different fields including gabbroic, diorite and syenite, and the volcanic rocks plot within basaltic, trachybasalt, pheno-tephrite, and trachy-andesite.
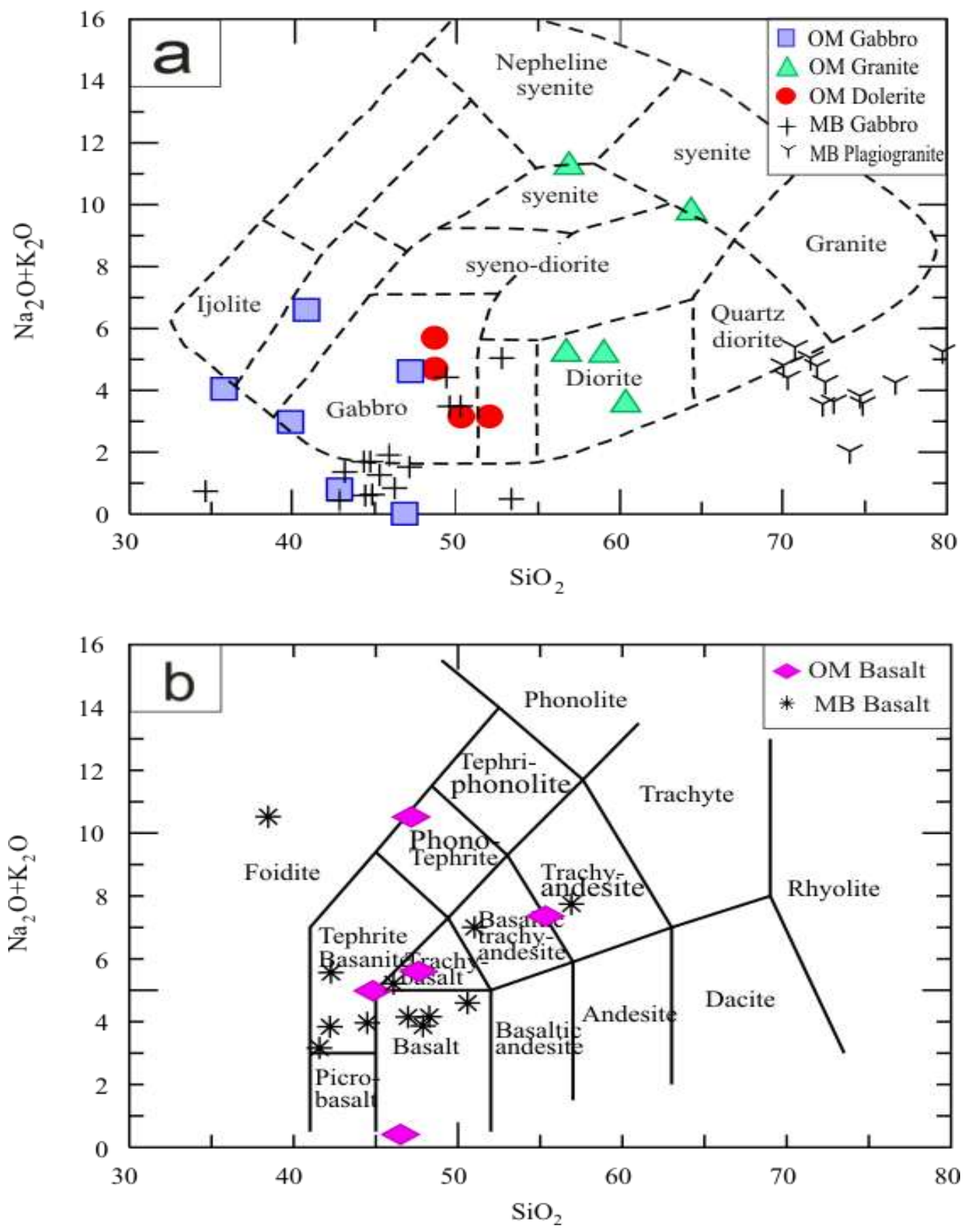

Figure 4: a-b Total alkali versus SiO2 plots: (a) plutonic rocks Cox, Bell [40] (b) volcanic rocks BAS, Maitre [41], of the analyses from the rocks of Omzha block, Zhob Ophiolite. The MB data are published earlier in [4, 42] Key: OM = Omzha block, MB = Muslim Bagh Ophiolite.

\subsubsection{Gabbroic Rocks}

The gabbroic rocks of Omzha block have the concentrations (wt. \%) of $\mathrm{SiO}_{2}(36-46), \mathrm{Al}_{2} \mathrm{O}_{3}(21-32), \mathrm{MgO}(11-20), \mathrm{Fe}_{2} \mathrm{O}_{3}(0-0.6), \mathrm{TiO}_{2}(0.01-0.03), \mathrm{Na}_{2} \mathrm{O}+\mathrm{K}_{2} \mathrm{O}$ (0.1-10), $\mathrm{MnO}$ (0.01-0.12) $\mathrm{P}_{2} \mathrm{O}_{5}$ (0-0.02) and $\mathrm{CaO}$ (2-7) and the analysed trace elements have the concentration (ppm) $\mathrm{Cr}$ (10-255), Ni (53-314), Co (13-46), $\mathrm{Pb}$ (3-58), $\mathrm{Zn}(16-24)$ and $\mathrm{Cu}$ (29-200). On the TAS diagram, nearly all of the samples fall in the gabbro field and having extremely low values of the alkali and silica (Figure 4a). On the fractionation index analyses of the gabbroic rocks of the Omzha block (Figure 5), with Ni, Pb, Fe2O3 the MgO shows a positive correlation and with $\mathrm{SiO}_{2}, \mathrm{Al}_{2} \mathrm{O}_{3}, \mathrm{Na}_{2} \mathrm{O}+\mathrm{K}_{2} \mathrm{O}, \mathrm{TiO}_{2}$, $\mathrm{CaO}$ it shows negative correlation and has no such correlation with $\mathrm{Mn}, \mathrm{Co}, \mathrm{Zn}$. The samples have a minor degree of scattering in most of the plots. 


\subsubsection{Granitic Rocks}

The major oxides of the granitic rocks have the concentration (wt. \%) of $\mathrm{Al}_{2} \mathrm{O}_{3}$ (23-32), $\mathrm{SiO}_{2}$ (55-64), $\mathrm{TiO}_{2}(0-0.04), \mathrm{Fe}_{2} \mathrm{O}_{3}(0-0.5), \mathrm{MnO}(0-0.05) \mathrm{MgO}(0.07-$ 11), $\mathrm{CaO}(0.5-3), \mathrm{Na}_{2} \mathrm{O}+\mathrm{K}_{2} \mathrm{O}$ (5-17) $\mathrm{P}_{2} \mathrm{O}$ (0-0.5) and the analysed trace elements have the concentration (ppm) $\mathrm{Co}(48-14), \mathrm{Ni}(0-85), \mathrm{Cr}(0-4) \mathrm{Pb}(16-42)$, $\mathrm{Zn} \mathrm{(9-23)} \mathrm{and} \mathrm{Cu}$ (89-755), and. On the total alkali versus $\mathrm{SiO}_{2}$ (TAS) diagram, the granitic rocks fall in the diorite, nepheline syenite and syenite field (Figure 4a).On the fractionation index analyses of the granitic rocks of the Omzha block (Figure 5), with $\mathrm{Al}_{2} \mathrm{O}_{3}, \mathrm{CaO}$, $\mathrm{MgO}$ shows a positive correlation, while it shows a negative correlation with $\mathrm{P}_{2} \mathrm{O}_{5}, \mathrm{Na}_{2} \mathrm{O}+\mathrm{K}_{2} \mathrm{O}, \mathrm{Mn}, \mathrm{Co}$, $\mathrm{Zn}$, $\mathrm{Cu}$ and have no such correlation with $\mathrm{SiO}_{2}, \mathrm{Fe}_{2} \mathrm{O}_{3}, \mathrm{TiO}_{2}, \mathrm{Cr}, \mathrm{Pb}, \mathrm{Ni}$.
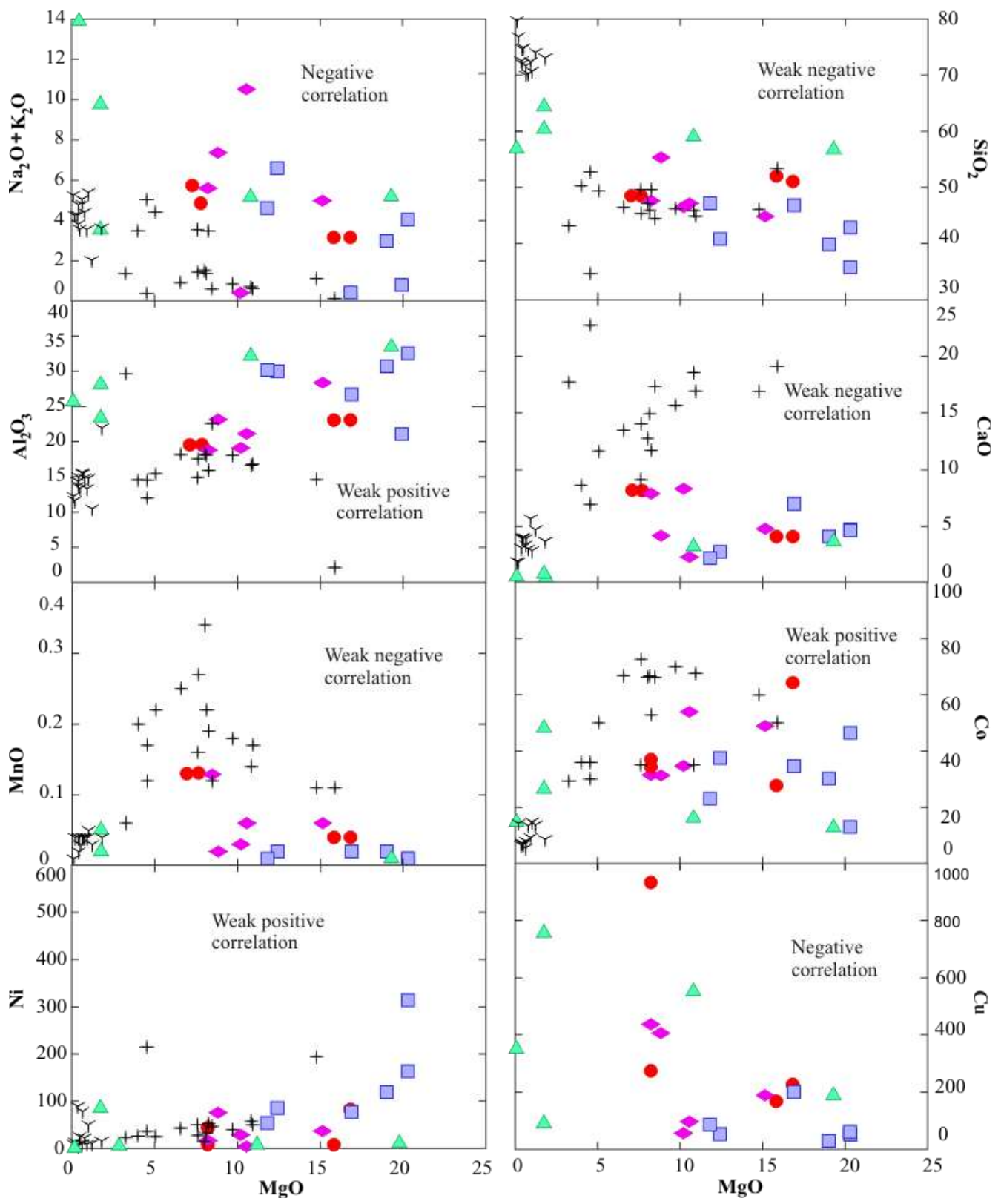

Figure 5: MgO versus major and selected trace element plots of the Omzha block of Zhob Ophiolite. (Symbols are the same as in Fig.4).

\subsubsection{Volcanic Rocks}

The major oxides of the volcanic rock have the concentration (wt. \%) of $\mathrm{SiO}_{2}$ (45-55), $\mathrm{TiO}_{2}(0.1-0.9), \mathrm{Al}_{2} \mathrm{O}_{3}(19-28), \mathrm{Fe}_{2} \mathrm{O}_{3}(0-8), \mathrm{MnO}(0.02-0.1) \mathrm{MgO}$ (8-15), $\mathrm{CaO}(2-8), \mathrm{Na}_{2} \mathrm{O}+\mathrm{K}_{2} \mathrm{O}(0.5-14), \mathrm{P}_{2} \mathrm{O}(0.01-1)$ and the analysed trace elements have the concentration (ppm) of $\mathrm{Cr}(1-82), \mathrm{Ni}(4-76), \mathrm{Co}(31-54) \mathrm{Pb}(25-74)$, $\mathrm{Zn} \mathrm{(26-143)} \mathrm{and} \mathrm{Cu}$ (57-437).On the TAS diagram, the samples fall in the trachy basalt, basalt, phono-tephrite and trachy andesite fields (Figure 4b). On the fractionation index analyses of the volcanic rocks of the Omzha block (Figure 5), $\mathrm{MgO}$ shows a positive correlation with $\mathrm{Al}_{2} \mathrm{O}_{3}, \mathrm{P}_{2} \mathrm{O}_{5}, \mathrm{Co}, \mathrm{Pb}, \mathrm{Zn}$, and have the negative correlation with $\mathrm{Na}_{2} \mathrm{O}+\mathrm{K}_{2} \mathrm{O}, \mathrm{SiO}_{2}, \mathrm{Fe}_{2} \mathrm{O}_{3}, \mathrm{CaO}$, $\mathrm{Cu}$ and have no such correlation with $\mathrm{TiO} 2, \mathrm{Mn}, \mathrm{Cr}, \mathrm{Ni}$.

\subsubsection{Dolerite}

The major oxides of the doleritic rocks have concentration (wt. \%) $\mathrm{Al}_{2} \mathrm{O}_{3}(20-23), \mathrm{SiO}_{2}$ (48-52), $\mathrm{TiO}_{2}$ (0.07-0.9), $\mathrm{Fe}_{2} \mathrm{O}_{3}(0.7-8), \mathrm{MnO}(0.04-0.1) \mathrm{MgO}$ (8-17), $\mathrm{CaO}$ (4-8), $\mathrm{Na}_{2} \mathrm{O}+\mathrm{K}_{2} \mathrm{O}$ (3-6) and $\mathrm{P}_{2} \mathrm{O}(0.02-0.1)$ and the selected trace elements have the concentration (ppm) $\mathrm{Cr}(2-38), \mathrm{Ni}(44-82), \mathrm{Co}(34-64), \mathrm{Pb}(3-31)$, $\mathrm{Zn}(33-58)$ and $\mathrm{Cu}(168-933)$. On the total alkali versus $\mathrm{SiO}_{2}$ (TAS) diagram, the doleritic rocks fall in the gabbroic field (Figure 4a).

\subsection{Discussion}

Omzha block is the smallest block, among the three-block of the Zhob Ophiolite, which is highly deformed and has not a complete stratigraphy as that of Muslim Bagh, Khanozai, and Bela ophiolites exposed in the area. The lithology of the Omzha block could be divided into the following units, (1) Ultramafic rock unit, (2) Mafic-felsic rock unit, (3) Volcanic-volcaniclastic-pelagic sediments and (4) Mafic dike. These lithologies depict the structure of the block as either a dismembered ophiolite or give a sense of a mélange. As the major element geochemistry of rock is not that useful compared to the trace element geochemistry. We have major element analyses of the studied rocks to divide the rocks only additional trace element data is required to determine the magma source, evolution and emplacement history. Anyway, the major element geochemistry of the plutonic rocks and volcanic rocks of the Omzha block divide them into a range of subdivisions. Crustal plutonic rocks identified are gabbroic, diorite and syenite while that of volcanic rocks are basalt, trachy basalt, phenol-tephrite, and trachy-andesite. 
A thick section of the Omzha peridotite exposed is dominantly harzburgite and associated dunite and a minor lherzolite. It is deformed and has altered into serpentinite maybe during and after their emplacement [19]. The harzburgite dominated mantle section shows that it is depleted in nature and may be residual after the mantle processes such as partial melting and the melt-rock reaction of a lherzolite source [20]. Many mafic dikes (now altered into rodingite) are intruded discordantly into peridotite, their contact relationship with host rock shows that they may be intruded later after the cooling of their country rocks.

Mafic-felsic rocks unit (gabbro, diorite, syenite, and granite) is highly deformed is formed by the crustal fractionation processes in a magma chamber. Intermediate-felsic rocks are dominant, in the form of veins, dikes and massive bodies within the crustal section of Omzha block. These rocks represent a later magmatic event in the crustal plutonic section of ophiolite and may be originated due to partial melting of the mafic rocks Amri, Benoit, late-stage fractional crystallization of mafic melt Coleman and Peterman, or silicate-liquid immiscibility of crustal mafic rocks [21-27]. Generally, Oceanic granites are called as plagiogranites, trondhjemites or leucocratic rocks, which are commonly associated with gabbroic rocks Khan and Khan, and are also reported in Muslim Bagh ophiolite Cox, Kerr, Bela ophiolite [26,28-31]. The highly deformed crustal section and the ultramafic rocks in the study area may be due to the tectonic activity during and after emplacement.

Volcanic-volcaniclastic-pelagic sediments found in the Omzha block could be part of the accretionary complex or mélange, and this mélange could be correlated with that found beneath the Muslim Bagh ophiolite called as Bagh Complex, Kakar, Mahmood, beneath Khanozai Ophiolite Ali , Kakar I Muhammad and the Waziristan Ophiolite as Vezhda Sar nappe [29-33]. Metamorphic sole rocks are widely accepted as the product of dynamothermal metamorphism, linked to the emplacement process of an ophiolite [34,35]. The metamorphic sole rocks are found at different localities in the 0 mzha block of the Zhob Ophiolite, such type of rocks are also found beneath other ophiolites such as Khanozai Ophiolite, Muslim Bagh Ophiolite Semail Oman ophiolite, and ophiolites in Turkey [37-39]. The sole rocks of Omzha block identified as amphibolites, quartz-mica schist, and greenschist, with highly developed microstructures i.e. foliation and lineation. These rocks may have their protolith from the ophiolitic rocks of the mapped area.

\subsection{Conclusions}

From the above discussion the following conclusions are drawn:

1. The Omzha block of Zhob Ophiolite is mapped for the first time and is divided into ultramafic rocks unit, mafic-felsic rocks unit, volcanicvolcaniclastic-pelagic rocks unit, and metamorphic sole rocks. All the units are highly deformed and are associated with one another by a thrust fault.

2. The ultramafic rocks of the Omzha block are dominantly serpentinized harzburgite, dunite, and a minor lherzolite. They may be depleted in nature and may have residual after processes such as partial melting and the melt-rock reaction of a lherzolite source.

3. The gabbros of the block are less well-developed and highly deformed. They are intruded by intermediate-felsic igneous rocks such as diorite, plagiogranite and anorthosite. The gabbros may be the plutonic section of ophiolite crust and the intermediate-felsic igneous rocks may have formed by the anataxis of crustal gabbro.

4. In the volcanic-volcaniclastic-pelagic rocks unit, the volcanic rocks are mainly basalt, volcaniclastic rocks are hyaloclastite and tuff while the pelagic sediments are mainly chert with some limestone and mudstone. The volcanic-volcaniclastic-pelagic rocks unit is a subduction-accretion complex that may be corrected with Bagh complex found beneath the Muslim Bagh Ophiolite.

5. The metamorphic sole rocks of Omzha block are highly deformed and dismembered, are consisting of amphibolite, quartz-mica schist, and greenschist. The sole rocks may have formed during the initial itra-oceanic emplacement.

\section{Acknowledgments}

The current research is a component of a bigger project titled; "Geology, Petro-chemistry and Tectonic setting of Zhob Valley Ophiolite, Northwestern Pakistan" that is HEC, Pakistan financially supported under its National Research Program for Universities (NRPU) Project\# 3593 to M. Ishaq Kakar.

\section{References}

[1] J.B. Auden, “Afghanistan-West Pakistan", Geological Society, London, Special Publications, 4(1), Pp. 235-253, 1974.

[2] A.H. Robertson, "Overview of the genesis and emplacement of Mesozoic ophiolites in the Eastern Mediterranean Tethyan region", Lithos, 65(1-2), Pp. 1$67,2002$.

[3] C. Dupuis, "The Yarlung Zangbo Suture Zone ophiolitic mélange (southern Tibet): new insights from geochemistry of ultramafic rocks", Journal of Asian Earth Sciences, 25(6), Pp. 937-960, 2005.

[4] M.I. Kakar, "Supra-subduction zone tectonic setting of the Muslim Bagh Ophiolite, northwestern Pakistan: insights from geochemistry and petrology", Lithos, 202, Pp. 190-206, 2014.

[5] P. Tapponnier, "Mesozoic ophiolites, sutures, and arge-scale tectonic movements in Afghanistan", Earth and Planetary Science Letters, 52(2), Pp. 355$371,1981$.

[6] E. Gnos, A. Immenhauser, T. Peters, "Late Cretaceous/early Tertiary convergence between the Indian and Arabian plates recorded in ophiolites and related sediments", Tectonophysics, 271(1-2), Pp. 1-19, 1997.

[7] A. Popal, M.I. Kakar, M. Khan, "Geology and petrography of gabbroic rocks from Khanozai Ophiolite, Northwestern Pakistan", International Research Journal of Earth Sciences, 7(3), Pp. 10-22, 2019.

[8] A.H. Kazmi, and M.Q. Jan, “Geology and tectonics of Pakistan”, Graphic publishers, 1997.

[9] A. Sengor, "Tectonics of the Tethysides: orogenic collage development in a collisional setting", Annual Review of Earth and Planetary Sciences, 15(1), Pp. 213-244, 1987.

[10] F. Allemann, "Time of emplacement of the Zhob Valley ophiolites and Bela ophiolites, Baluchistan (preliminary report)", Geodynamics of Pakistan. Geological Survey of Pakistan, Quetta, P p. 215-242, 1979.

[11] A. Gansser, "Reconnaissance visit to the ophiolites in Baluchistan and the Himalaya”, Geodynamics of Pakistan, Pp. 193-213, 1979.

[12] A. Jones, "Reconnaissance Geology of part of West Pakistan (Colombo Plan co-operative project conducted and compiled by Hunting Survey 
Corporation)", Government of Canada, Toronto, 1960.

[13] T. Naka, "Mesozoic sedimentary-igneous Complex, Bagh complex, in the Muslim Bagh Area, Pakistan. opening and closing ages of the Ceno-Tetheyan branch", Proceedings of Geoscience Colloquium, Geoscience Laboratory, Geological Survey of Pakistan. 1996.

[14] A.K. Kasi, “Revised lithostratigraphy of the Pishin Belt, northwestern Pakistan”, Journal of Himalayan Earth Science, 45(1), 2012.

[15] M. Qayyum, A.R. Niem, and R.D. Lawrence, "Newly discovered Paleogene deltaic sequence in Katawaz basin, Pakistan, and its tectonic implications", Geology, 24(9), Pp. 835-838, 1996.

[16] E. Macalalad, "A concise analytical scheme for 16 trace elements in geochemical exploration samples using exclusively AAS", Journal of Geochemical Exploration, 30(1-3), Pp. 167-177, 1988.

[17] M.D. Williams, "Stratigraphy of the Lower Indus Basin, West Pakistan”, in 5th World petroleum congress. World Petroleum Congress, 1959.

[18] A. Fatmi, I. Hyderi, and M. Anwar, "Occurrence of the Lower Jurassic Ammonoid genus Boul eiceras from the surghar range with a revised nomenclature of the Mesozoic Rocks of the Salt Range and Trans Indus Ranges (Upper Indus Basin)”, Geol. Bull. Punjab Univ, 25, Pp. 38-46, 1990.

[19] A. Nicolas, "Structures of ophiolites and dynamics of oceanic lithosphere”, Springer Science \& Business Media, Vol. 4. 2012.

[20] M.I. Kakar, "Petrology of the mantle rocks from the Muslim Bagh Ophiolite, Balochistan, Pakistan”, Journal of Himalayan Earth Science, $46(2), 2013$.

[21] I. Amri, M. Benoit, G. Ceuleneer, "Tectonic setting for the genesis of oceanic plagiogranites: evidence from a paleo-spreading structure in the Oman ophiolite", Earth and Planetary Science Letters, 139(1-2), Pp. 177-194, 1996.

[22] D.C. Gerlach, W.P. Leeman, and H.G.A. Lallemant, "Petrology and geochemistry of plagiogranite in the Canyon Mountain Ophiolite, Oregon", Contributions to Mineralogy and Petrology, 77(1), Pp. 82-92, 1981.

[23] K. Gillis, and L. Coogan, "Anatectic migmatites from the roof of an ocean ridge magma chamber", Journal of Petrology, 43(11), Pp. 2075-2095, 2002.

[24] L. France, "Hydrous partial melting in the sheeted dike complex at fast spreading ridges: experimental and natural observations", Contributions to Mineralogy and Petrology, 160(5), Pp. 683-704, 2010

[25] M. Erdmann, "Anatexis at the roof of an oceanic magma chamber at IODP Site 1256 (equatorial Pacific): an experimental study", Contributions to Mineralogy and Petrology, 169(4), p. 39, 2015.

[26] R. Coleman, and Z. Peterman, “Oceanic plagiogranite”, Journal of Geophysical Research, 80(8), Pp. 1099-1108, 1975.

[27] S. Dixon, and M. Rutherford, "Plagiogranites as late-stage immiscible liquids in ophiolite and mid-ocean ridge suites: an experimental study", Earth and Planetary Science Letters, 45(1), Pp. 45-60, 1979.

[28] S.R. Khan, and M.A. Khan, "Petrology and Geochemistry of Trondhjemites From The Waziristan Ophiolite, Nw Pakistan", Journal Of Himalayan Earth Sciences, 36, 2003

[29] M.I. Kakar, "Geochemistry and petrogenesis of the volcanic rocks from Bagh complex, northern Balochistan, Pakistan", Journal of Himalayan Earth Sciences, 45(1), Pp. 17-29, 2012.

[30] H. Rollinson, “New models for the genesis of plagiogranites in the Oman ophiolite”, Lithos, 112(3-4), Pp. 603-614, 2009.

[31] D. Cox, "Petrogenesis of plagiogranites in the Muslim Bagh Ophiolite, Pakistan: implications for the generation of Archaean continental crust", Geological Magazine, 156(5), Pp. 874-888, 2019.

[32] Ali, "Petrology And Major Element Geochemistry Of Volcanic Rocks Beneath The Khanozai Ophiolite, Balochistan, Pakistan”, Bahria University Research Journal of Earth Sciences, 4(1), Pp. 40-45, 2019.

[33] M. Khan, A.C. Kerr, and K. Mahmood, "Formation and tectonic evolution of the Cretaceous-Jurassic Muslim Bagh ophiolitic complex, Pakistan: Implications for the composite tectonic setting of ophiolites", Journal of Asian Earth Sciences, 31(2), Pp. 112-127, 2007.

[34] R.A. Jamieson, "P-T paths from high temperature shear zones beneath ophiolites", Journal of Metamorphic Geology, 4(1), Pp. 3-22, 1986.

[35] J. Malpas, "The dynamothermal aureole of the Bay of Islands ophiolite suite", Canadian Journal of Earth Sciences, 16(11), Pp. 2086-2101, 1979.

[36] M. Searle, and J. Malpas, "Structure and metamorphism of rocks beneath the Semail ophiolite of Oman and their significance in ophiolite obduction", Earth and Environmental Science Transactions of the Royal Society of Edinburgh, 71(4), Pp. 247-262. 1980.

[37] J.N. Lytwyn, and J.F. Casey, "The geochemistry of postkinematic mafic dike swarms and subophiolitic metabasites, Pozanti-Karsanti ophiolite, Turkey: Evidence for ridge subduction", Geological Society of America Bulletin, 107(7), Pp. 830-850, 1995.

[38] 0. Parlak, H. Yilmaz, and D. Boztuğ, "Origin and tectonic significance of the metamorphic sole and isolated dykes of the Divriği ophiolite (Sivas, Turkey): evidence for slab break-off prior to ophiolite emplacement”, Turkish Journal of Earth Sciences, 15(1), Pp. 25-45, 2006.

[39] O.F. Çelik, and M.F. Delaloye, "Characteristics of ophiolite-related metamorphic rocks in the Beysehir ophiolitic mélange (Central Taurides, Turkey), deduced from whole rock and mineral chemistry", Journal of Asian Earth Sciences, 26(5), Pp. 461-476, 2006.

[40] K. Cox, J. Bell, and R. Pankhurst, “The Interpretation of Igneous Rocks", Allen and Unwine, London, 450 p. 1979.

[41] M.L. Bas, "A chemical classification of volcanic rocks based on the total alkali-silica diagram", Journal of petrology, 27(3), Pp. 745-750, 1986.

[42] M.I. Kakar, "U-Pb zircon crystallization age of the Muslim Bagh ophiolite: Enigmatic remains of an extensive pre-Himalayan arc", Geology, 40(12), Pp. 1099-1102, 2012. 